\title{
Composition of molding material for ceramic tiles
}

\author{
Vladimir Adamyan ${ }^{1}$, Svetlana Kalashnikova ${ }^{1}$, Victoria Burlakova $^{1}$, Luiza Seferyan $^{2 *}$, and \\ Galina Sergeeva ${ }^{1}$ \\ ${ }^{1}$ Don State Technical University, 344002, Rostov-on-Don, Russia \\ ${ }^{2}$ Rostov-on-Don College of Communication and Informatics, 344000, Rostov-on-Don, Russia
}

\begin{abstract}
This article discusses the problems of creating new compositions for ceramic tiles. There are two ways to process the composition of the molding material - dry and wet. A description of the wet processing method is given. The molding of the plastic mass is carried out by pressing to obtain a tile with a size of $50 \times 150 \mathrm{~mm}$. The molded product goes through the following stages of the technological regime: blowing in a drying stove with an increase in temperature from $25^{\circ} \mathrm{C}$ to $700{ }^{\circ} \mathrm{C}$ for 3-4 hours. Further, at a speed of $15-20$ degrees per minute, the temperature rises to $1050{ }^{\circ} \mathrm{C}$ and then the heat treatment continues for 30 minutes. After annealing, the product is cooled and tested.
\end{abstract}

\section{Introduction}

Various sectors of the national economy use ceramic products - bricks, tiles for wall and floor cladding, sanitary and technical ceramics.

One of the most important stages for the formation of ceramics is the initial composition and mass of the materials processed by various methods. The main processing methods are dry and wet. Due to the high energy consumption, the wet method is more expensive but gives better results [1].

Various minerals can be used in the line mass. For example, according to the requirements of GOST (GOST R 56828.20-2017 Best available technologies. Production of ceramic tiles. Aspects of increasing energy and environmental efficiency), for the production of ceramic tiles, a composition that includes clay to ensure the plasticity of the molding mass, quartz sand, which forms the structure and the skeleton of the product is used, as well as feldspars and carbonates, which impart viscosity to the product and a glassy surface $[2,3]$.

\section{Material and research methods}

The composition of the molding material considered in this article differs from the standard one in respect that the molding material composition for ceramic tiles, including bentonite

\footnotetext{
${ }^{*}$ Corresponding author: Luiza.seferyan@mail.ru
} 
clay, calcium silicate, aluminum potassium sulphate and calcium oxide in the following ratios of components (wt $\%)$

$\begin{array}{cc}\text { Bentonite clay } & 35-50 \\ \text { Calcium silicate } & 25-30 \\ \text { Aluminum potassium sulphate } & 15-20 \\ \text { Calcium oxide } & 10-15\end{array}$

In the manufacture of facing tiles, the molding of products was carried out in a plastic way. The clay was crushed and mixed in a mixer with the pre-crushed remaining components in the calculated mass ratios. The mixture has acquired the appearance of a homogeneous plastic mass $[4,5]$.

The molding of the plastic mass is carried out by pressing to obtain a tile with a size of $50 \times 150 \mathrm{~mm}$.

\section{Research results and their discussion.}

Shaped product - tiles - in a drying plant at an initial temperature $25{ }^{\circ} \mathrm{C}$ are blown with air with a gradual increase in temperature to $700{ }^{\circ} \mathrm{C}$ within $3-4$ hours. At the same time, moisture forms on the surface of the semi-finished product, which quickly evaporates and is removed by the ventilation system. In addition, by this time, complete desulfurization of aluminum potassium sulphate is achieved $[6,7]$.

Alum-aluminum potassium sulphate is converted into aluminum oxide as a result of stepwise thermal dissociation (1).

$$
\mathrm{K}_{2} \mathrm{SO}_{4} \cdot \mathrm{Al}_{2}\left(\mathrm{SO}_{4}\right)_{3} \rightarrow \mathrm{K}_{2} \mathrm{SO}_{4}+\mathrm{Al}_{2} \mathrm{O}_{3}+3 \mathrm{SO}_{2}
$$

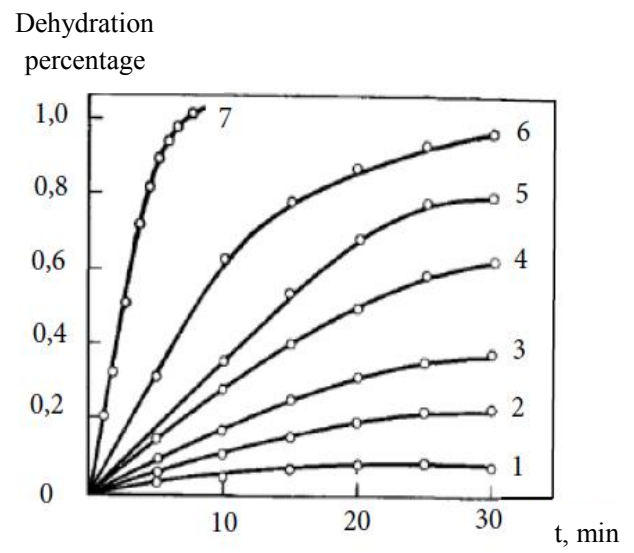

Fig. 1. Kinetic curves of aluminum potassium sulphate dehydration at a temperature, ${ }^{0} \mathrm{C}: 1-40 ; 2-$ $50 ; 3-60 ; 4-70 ; 5-150 ; 6-200 ; 7-350$.

At a temperature $680-700{ }^{\circ} \mathrm{C}$ the kinetics of the desulfurization rate reaches its maximum value $\mathrm{K}=0.06 \mathrm{~min}^{-1}$ (Fig. 2) 




Fig. 2. Kinetic curve of desulfurization of aluminum potassium sulphate in an inert atmosphere

As it can be seen from Figure 2, desulfurization rate starts increasing sharply already at a temperature $600{ }^{0} \mathrm{C}$, reaching its maximum value at $700{ }^{\circ} \mathrm{C}$. Further, the rate of desulfurization of aluminum potassium sulphate is reduced to a decrease, and complete desulfurization is achieved at a temperature $900{ }^{\circ} \mathrm{C}$. Further heating of the system leads to insignificant (up to $6 \%$ ) aluminate formation $[8,9]$.

After the desulfurization process at a speed of 15-20 degrees per minute, the temperature rises to $1050{ }^{\circ} \mathrm{C}$ and then heat treatment continues for 30 minutes. Under these conditions, a polymorphic transition of the metastable form of aluminum oxide to aluminum oxide occurs $\mathrm{C}-\delta-\mathrm{Al}_{2} \mathrm{O}_{3}$, with a strong oxidative-catalytic effect.

Aluminum oxides are usually obtained by dehydration of aluminum hydroxide at a temperature $300{ }^{\circ} \mathrm{C}$. At a temperature $500-600{ }^{\circ} \mathrm{C}$ metastable forms of various crystalline modifications are formed $\left(\gamma-\mathrm{Al}_{2} \mathrm{O}_{3}, \eta-\mathrm{Al}_{2} \mathrm{O}_{3}, \chi-\mathrm{Al}_{2} \mathrm{O}_{3}\right)$. The resulting metastable forms are fairly stable to heat treatment, without changing their crystalline modification, up to 800$900{ }^{\circ} \mathrm{C}$. With a further increase in temperature to $1100{ }^{\circ} \mathrm{C}$ received modifications $\gamma-\mathrm{Al}_{2} \mathrm{O}_{3}$, $\eta-\mathrm{Al}_{2} \mathrm{O}_{3}, \chi-\mathrm{Al}_{2} \mathrm{O}_{3}$ pass, respectively, in the modifications $\delta-\mathrm{Al}_{2} \mathrm{O}_{3}, \theta-\mathrm{Al}_{2} \mathrm{O}_{3}$ and $\kappa-\mathrm{Al}_{2} \mathrm{O}_{3}$. At a temperature $1100-1200{ }^{\circ} \mathrm{C}$ all modifications go to $\alpha-\mathrm{Al}_{2} \mathrm{O}_{3}[10,11]$.

Alumina $\mathrm{C}$ contributes to the formation of a highly developed specific surface of the molded article and is a catalyst on the tile surface. In this case, a self-cleaning effect is created on the tile surface, the mechanism of which is that water flows under the dirt on the tile surface, washing it off, and in addition, when quanta are absorbed, a reaction occurs that splits the dirt on the tile. When absorbing quanta (ultraviolet radiation), it exhibits disinfecting properties [12].

Calcium oxide determines the finished molded material's strength.

Calcium oxide $\mathrm{CaO}$ is a white crystalline compound (GOST 8677-76). In terms of physical and chemical parameters, calcium oxide must comply with the standards specified in Table 1.

Table 1. Physical and chemical parameters of calcium oxide

\begin{tabular}{|l|c|}
\hline \multicolumn{1}{|c|}{ Indicator name } & Norm \\
\cline { 2 - 2 } & Clean (c) RCP 26 1121035106 \\
\hline $\begin{array}{l}\text { 1. Mass fraction of calcium oxide }(\mathrm{CaO}), \% \text {, not } \\
\text { less }\end{array}$ & 96.0 \\
\hline $\begin{array}{l}\text { 2. Mass fraction of calcium carbonate }\left(\mathrm{CaCO}_{3}\right), \%, \\
\text { no more }\end{array}$ & 2.5 \\
\hline
\end{tabular}




\begin{tabular}{|l|c|}
\hline $\begin{array}{l}\text { 3. Mass fraction of substances insoluble in } \\
\text { hydrochloric acid, } \% \text {, no more }\end{array}$ & 0.02 \\
\hline 4. Mass fraction of total nitrogen $(\mathrm{N}), \%$, no more & 0.06 \\
\hline 5. Mass fraction of sulfates $\left(\mathrm{SO}_{4}\right), \%$, no more & 0.05 \\
\hline 6. Mass fraction of chlorides $(\mathrm{Cl}), \%$, no more & 0.010 \\
\hline 7. Mass fraction of iron $(\mathrm{Fe}), \%$, no more & 0.02 \\
\hline 8. Mass fraction of heavy metals $(\mathrm{Pb}), \%$, no more & 0.010 \\
\hline $\begin{array}{l}\text { 9. Mass fraction of the sum of potassium and } \\
\text { sodium }(\mathrm{K}+\mathrm{Na}), \%, \text { no more }\end{array}$ & Not standardized \\
\hline
\end{tabular}

The content of calcium oxide in the molding material increases with the decomposition of calcium silicate - a source of silicon oxide in the general composition. [13]

The work uses carbonate-palygorskite bentonite clay with a chemical composition (Table 2):

Table 2. Chemical composition of bentonite carbonate-palygorskite clay

\begin{tabular}{|c|c|c|c|c|c|c|c|c|c|c|c|c|}
\hline Name & $\mathrm{SIO}_{2}$ & $\mathrm{TIO}_{2}$ & $\mathrm{Al}_{2} \mathrm{O}_{3}$ & $\mathrm{Fe}_{2} \mathrm{O}_{3}$ & $\mathrm{MgO}$ & $\mathrm{CaO}$ & $\mathrm{Na}_{2} \mathrm{O}$ & $\mathrm{K}_{2} \mathrm{O}$ & $\mathrm{P}_{2} \mathrm{O}_{5}$ & $\mathrm{SO}_{3}$ & $\mathrm{FeO}$ & $\mathrm{H}_{2} \mathrm{O}$ \\
\hline $\begin{array}{l}\text { Carbonate- } \\
\text { palygorskite } \\
\text { clay }\end{array}$ & 46.79 & - & 8.63 & - & 2.74 & 10.08 & - & 1.60 & 1.99 & - & 3.41 & 24.33 \\
\hline
\end{tabular}

\section{Conclusion}

After ignition, the product is cooled and tested [14, 15].

After cooling, the tiles do not need to be coated with an oxide-ceramic coating, since the entire internal structure of the product is similar to the external one.

The test results are shown in Table 3.

Table 3. Results of testing ceramic tiles

\begin{tabular}{|c|c|c|c|c|c|c|c|c|c|}
\hline \multirow[b]{2}{*}{ 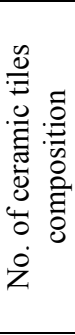 } & \multicolumn{4}{|c|}{$\begin{array}{l}\text { Components of the } \\
\text { original mixture }\end{array}$} & \multicolumn{5}{|c|}{ Physical indicators } \\
\hline & $\begin{array}{l}\frac{\pi}{0} \\
0 \\
.0 \\
0 \\
0 \\
000 \\
0\end{array}$ & 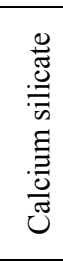 & 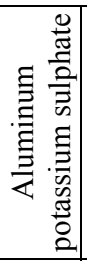 & 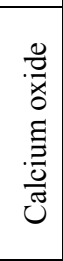 & $\begin{array}{c}\text { Fle- } \\
\text { xural } \\
\text { stren- } \\
\text { gth, } \\
\text { MPa }\end{array}$ & $\begin{array}{c}\text { Breaking } \\
\text { strength, } \\
\text { kg }\end{array}$ & $\begin{array}{c}\text { Water } \\
\text { absorp- } \\
\text { tion, } \\
\%\end{array}$ & $\begin{array}{c}\text { Contact } \\
\text { angle of } \\
\text { wetting with } \\
\text { a drop of } \\
\text { water with a } \\
\text { volume } 10 \\
\text { mcl }\end{array}$ & $\begin{array}{c}\text { Specific } \\
\text { surface in } \\
\text { the range, } \\
\mathrm{m}^{2} / \mathrm{g}\end{array}$ \\
\hline 1 & 60 & 20 & 12 & 8 & 60.3 & 130.2 & - & $149^{0}$ & 110 \\
\hline 2 & 50 & 25 & 15 & 10 & 63.7 & 155.1 & - & $142^{0}$ & 120 \\
\hline 3 & 42 & 27 & 18 & 13 & 60.4 & 187.2 & - & $155^{0}$ & 140 \\
\hline 4 & 35 & 30 & 20 & 15 & 62.4 & 149.6 & 0.1 & $130^{\circ}$ & 113 \\
\hline 5 & 30 & 32 & 22 & 16 & 61.3 & 151.3 & - & $145^{0}$ & 113 \\
\hline
\end{tabular}




\section{References}

1. Yu.I. Goncharov, V.S. Lesovik, M.Yu. Goncharova, V.V. Strokova, Mineralogy and petrography of raw materials for the production of building materials and technical ceramics, 2001.

2. V.S. Lesovik, Laboratory workshop on building materials, 2004.

3. A.S. Boldyrev, P.P. Zolotov, A.N. Lyusov et al., Building materials (Stroyizdat, Moscow, 1989).

4. K.V. Chaus, Yu.D. Chistov, Yu.V. Labzina, Manufacturing technology of building materials, products and structures (Stroyizdat, Moscow, 1998).

5. G.A. Sergeeva, V.L. Adamyan, Intelligent systems in production 1 (32), 114-117 (2017).

6. G.A. Sergeeva, L.L. Volobueva, E.A. Krivosheeva, Debris flow hazard of the Karachay-Cherkess Republic, Western Caucasus, Monograph, Palmarium Akademic Publishing, 2015.

7. S.G. Sheina, L.V. Girya, Innovative methods of monitoring for deformations of manmade loaded areas, MATEC Web of Conferences. International scientific and technical conference "Modern directions and prospects for the development of processing technologies and equipment in mechanical engineering 2017", (ISSN: 2261236X, France).

8. G.A. Sergeeva, V.L. Adamyan, Serious areas in the Pshekha river basin, Ecology and life safety. Collection of articles of the XVII International Scientific and Practical Conference 135-138 (2017).

9. L.A. Seferyan, V.E. Chubarov, K.V. Chubarova, IOP Conf. Series: Materials Science and Engineering 1083, 012049 (2021). doi:10.1088/1757-899X/1083/1/012049

10. V.L. Adamyan, G.A. Sergeeva, L.A. Seferyan, N.Y. Gorlova, IOP Conf. Series: Materials Science and Engineering 1083, 012050 (2021). doi:10.1088/1757899X/1083/1/012050.

11. S.B. Yazyeva, L.A. Seferyan, L.A. Oparina, A.Y. Golubeva, Materials Science Forum 931, 883-888 (2018).

12. L.A. Seferyan, T.N. Kondrateva, V.E. Morozov, I.V. Leusenko, IOP Conference Series: Materials Science and Engineering 698 (5), 055004 (2019)

13. S.G. Sheina, K.V. Yudina, Materials Science Forum 931, 822-826 (2018). URL: https://www.scientific.net/MSF.931.822.

14. V.L. Adamyan, G.A. Sergeeva, N.V. Kondratenko, D.V. Totskiy, V.O. Boyko, Science perspective 10, 7-9 (2016).

15. V.L. Adamyan, S.B. Kalashnikova, Patent RU 2730 140. The composition of the molding material for ceramic tiles. Published by 19.08.2020. Bul. No. 23. 